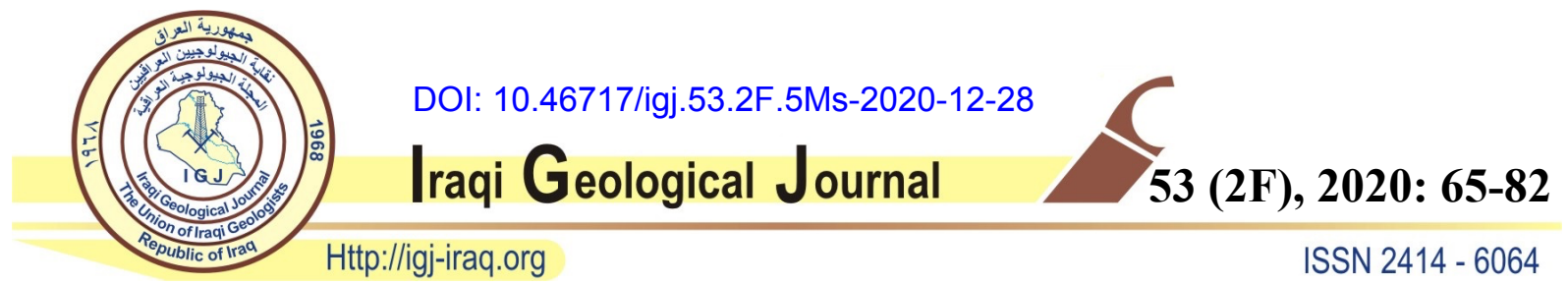

\title{
ENGINEERING GEOLOGICAL ASSESSMENT OF THE ROCK SLOPE STABILITY ALONG THE PROPOSED LERABIRE ROAD IN THE MERGASUR CITY, KURDISTAN, IRAQ
}

\author{
${ }^{1}$ Rebaz Muhammed Qader", ${ }^{1}$ Soran Hassen Arab and ${ }^{1}$ Mariwan Akram Hamahsaeed \\ ${ }^{1}$ Department of Geology, College of Science, University of Salahaddin, Erbil, Iraq \\ "E-mail: rebaz_qader@yahoo.com \\ Received: 4 July 2020; accepted: 27 October 2020
}

\begin{abstract}
The study of slope stability along the proposed Lerabire road in the Mergasur town, in Erbil city, Kurdistan region of NE-Iraq is carried out. To evaluate the stability of slopes, twenty stations were selected along the mentioned road, two stations in the rock slopes of the Shiranish Formation, eleven stations in the Bekhme Formation, six stations in the Qamchuqa Formation, and one station in the Sarmord Formation. In this study, the stability of rock slopes has been evaluated by Landslide Possibility Index system. The results of the Landslide Possibility Index category in the rock slopes along the proposed Lerabire road ranges from a very low to low for rock slopes in the stations 1 and 2 (marl and marly limestone of the Shiranish Formation, Moderate for rock slopes in the stations 3, 4 and 19 (limestone of the Bekhme Formation), High for rock slopes in the stations 5, 6, 7, 8, 9, 10, 11 (limestone of the Bekhme Formation), stations 12, 17 (limestone and marly limestone of the Qamchuqa Formation), station 20 (limestone of the Sarmord Formation and very high for rock slopes in the stations 13, 14, 15, 16 (limestone and marly limestone of the Qamchuqa Formation), station 18 (limestone of the Bekhme Formation). According to Landslide Possibility Index category the hazard category is Low in station 1 in the Shiranish Formation, but in station 2, 3, 4 and 19 are Moderate, moreover, in the station 5, 11, 12, 17, 18 and 20 are high. The rock slope assessment indicated that the height of the slope face, slope angle, high degree of weathering and discontinuities spacing are the factors that increase the failure possibility. To prevent landslide the ditch method is used in the Shiranish Formation rock slopes, the reinforcement techniques are used in the Behkme Formation rock slopes and rock removal method are used in Qamchuqa and Sarmord Formation rock slopes.
\end{abstract}

Keywords: Landside possibility index; Landslide; Stabilization; Rock slope 


\section{INTRODUCTION}

Evaluation of the stability slope along and around the road is a necessary assignment due to their effect on human life as well as properties. Determining the stability assessment for a proposed road has a significant effect on the civil work decision in rock slope faces, in addition base on that the cutting and the filling process depending on slope stability assessment. The study area comprises rock slopes of Shiranish, Behkme, Qamchuqa and Sarmord formations in the proposed Lerabire road are $144 \mathrm{~km}$ away to the NE of Erbil city, northern Iraq. The site is located near the Lerabire village in the Barzan district area, between latitude; $35^{\circ} 55^{\prime} 15^{\prime \prime}$ and $36^{\circ} 55^{\prime} 42^{\prime \prime}$ North, and longitude: $44^{\circ} 10^{\prime} 17^{\prime \prime}$ and $44^{\circ} 09^{\prime} 50^{\prime \prime}$ East. In addition, the working area occupies in a complex geological area between Shirin and Bradost Anticline (Fig. 1).

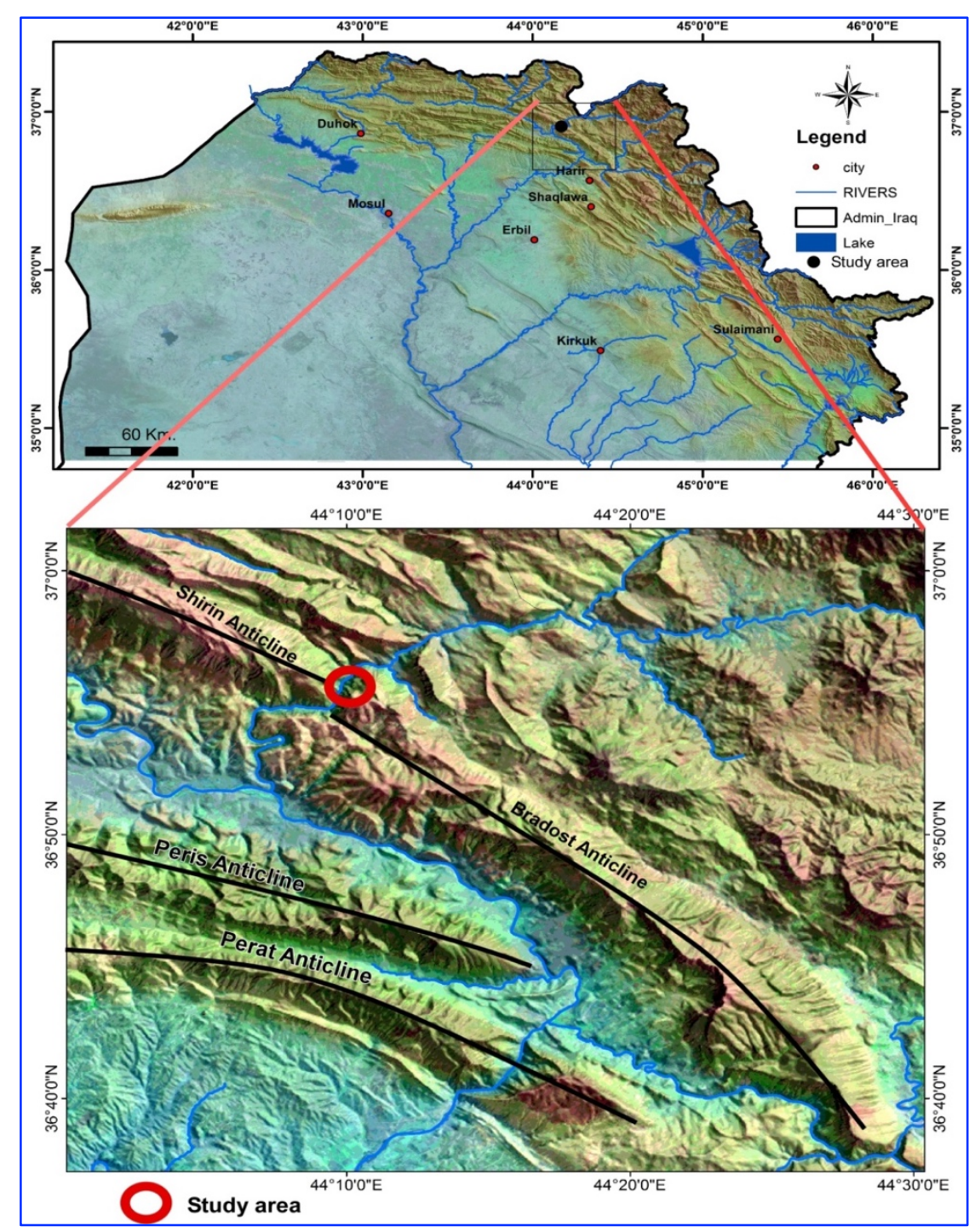

Fig. 1. Physical and structural map of the study area 
The previous studies in this area where the proposed road included are found in different geological subjects such as; Structural geology, Sedimentological, Stratigraphic, Hydrological and Geomorphological. Son et al (2020) mentioned that the load capacity of ground is improved by the PF column can be satisfied with the construction requirement. The unconfined compressive strength and elastic modulus of treated ground are high. Alhadad (2020) studied slope failure at Tikrit, northern Iraq and mentioned that the rock compressive strength played an important parameter in the stability of rocks in addition to water, slope high, slope angle, traffic, etc. Man-made affected the slope stability directly, vibrations, excavations. The present study aims to demonstrate the possibility of landslide for the rock slopes in the proposed Lerabire road during the road construction and process of cut and fill, Landslide Possibility Index (LPI) calculations, landslide potential hazard assessment by preparation of landslide hazard map and suggestion of some remediation techniques for the rock slopes along the road.

\section{GEOLOGICAL SETTING}

The geological setting of the studied area; including tectonics and structure, stratigraphy and geomorphology. The three main aspects are described briefly:

\section{A. Tectonics and Structural Geology}

The study area is located in the imbricated zone, the earthquake activity has the great influences on it, due to the complexity of the structural geology (Al-sinawi and Al-Qasrani, 2003). Shirin and Bradost anticlines are characterized by the presence of a number of major faults of different scales and types distributed everywhere within the anticline (Fouad, 2010; Jassim and Buday, 2006. According to Omar (2005), some of these faults are reversed types, and appear especially in the southwestern limb, others are normal or strike-slip faults, and the presence of such a large number of faults of different types and positions with it is closer to the main Zagros Thrust Zone suggest that the Bradost anticline is located within the imbricated Zone of the Iraqi tectonic divisions instead of the High Folded Zone (Buday and Jassim, 1987). Bradost anticline is asymmetrical, cylindrical anticlinal fold, extends for more than $60 \mathrm{~km}$ and trending NW-SE. Its half wavelength as measured from the middle part reaches up to $8 \mathrm{~km}$, while its amplitude in same part is about $2 \mathrm{~km}$ (Balaki and Omar, 2019). The northwest plunge located southeast Barzan town near Dore village and interfered with Shirin anticline. While, the southeast plunge located in Rawanduz town, which interfered with Korek anticline and an en-echelon with Handin anticline. The proposed road mostly located at the northwest plunge of the Bradost anticline and southeastern plunge of the Shirin anticline. 


\section{B. Stratigraphy}

The exposed geological units, at and around the study area, are represented by four formations which range in age from Early to Middle Cretaceous. Most of the anticlines around the study area are dominated by carbonate and the oldest unit of Lower Cretaceous age and it is defined as a Sarmord and Qamchuqa formations. Bekhme and Shiranish formations are characterized as an Upper Cretaceous age with carbonate and impure carbonate rocks, respectively. Only those Formations which are involved in the studied area and exhibit different slope stability condition are described briefly (Fig. 2).

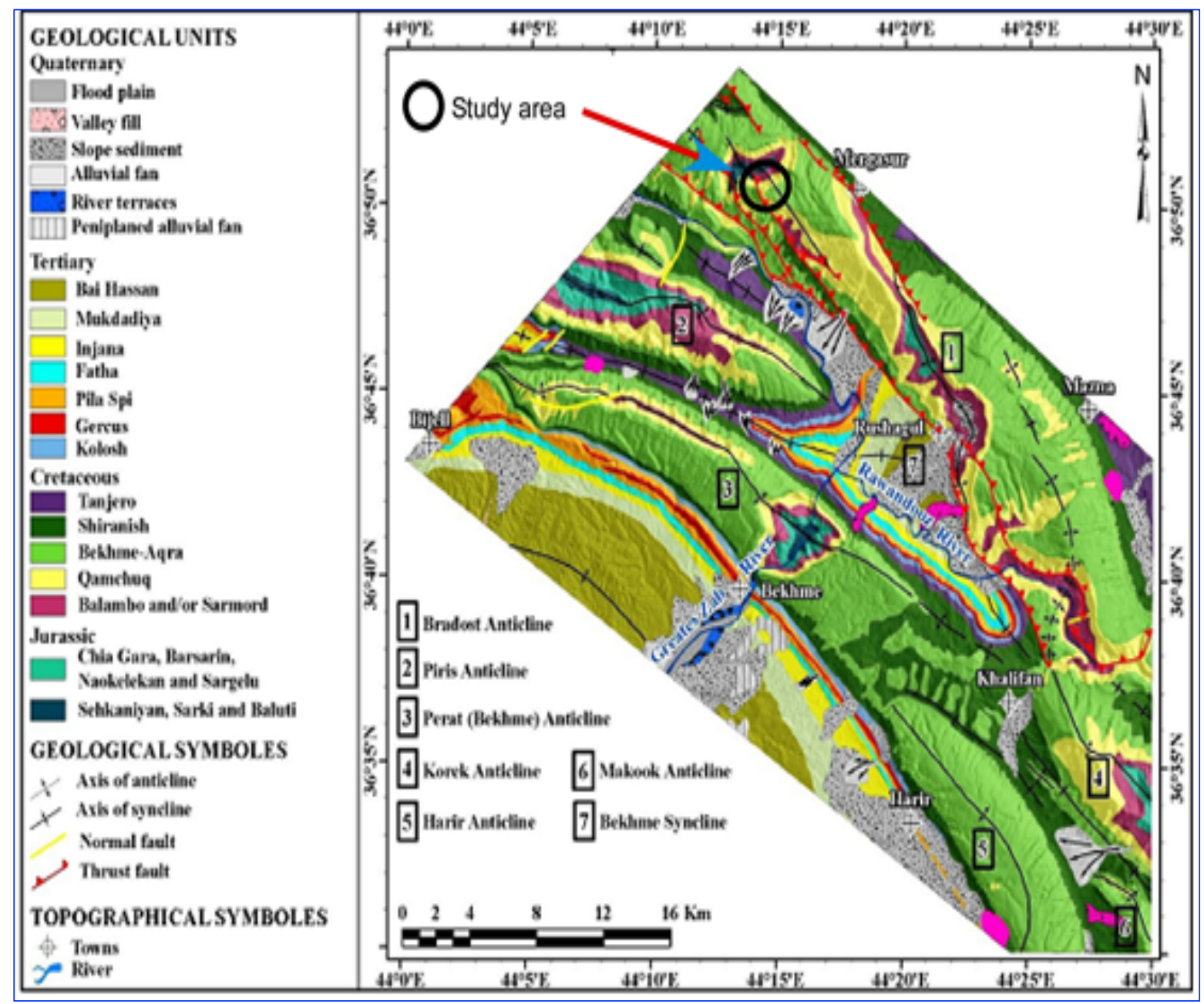

Fig. 2. Geological map of the study area (after Ibrahim et al., 1984 and Sissakian, 1998)

\section{Qamchuqa Formation}

It is composed the core of the Bradost anticline and appears in the northeastern limb, moreover, this Formation consists mainly of alternating massive to very hard coarse crystalline dolomites and argillaceous Limestone (Fig. 3), and more than $250 \mathrm{~m}$ thick (Sissakian and Al-Jiburi, 2014). 


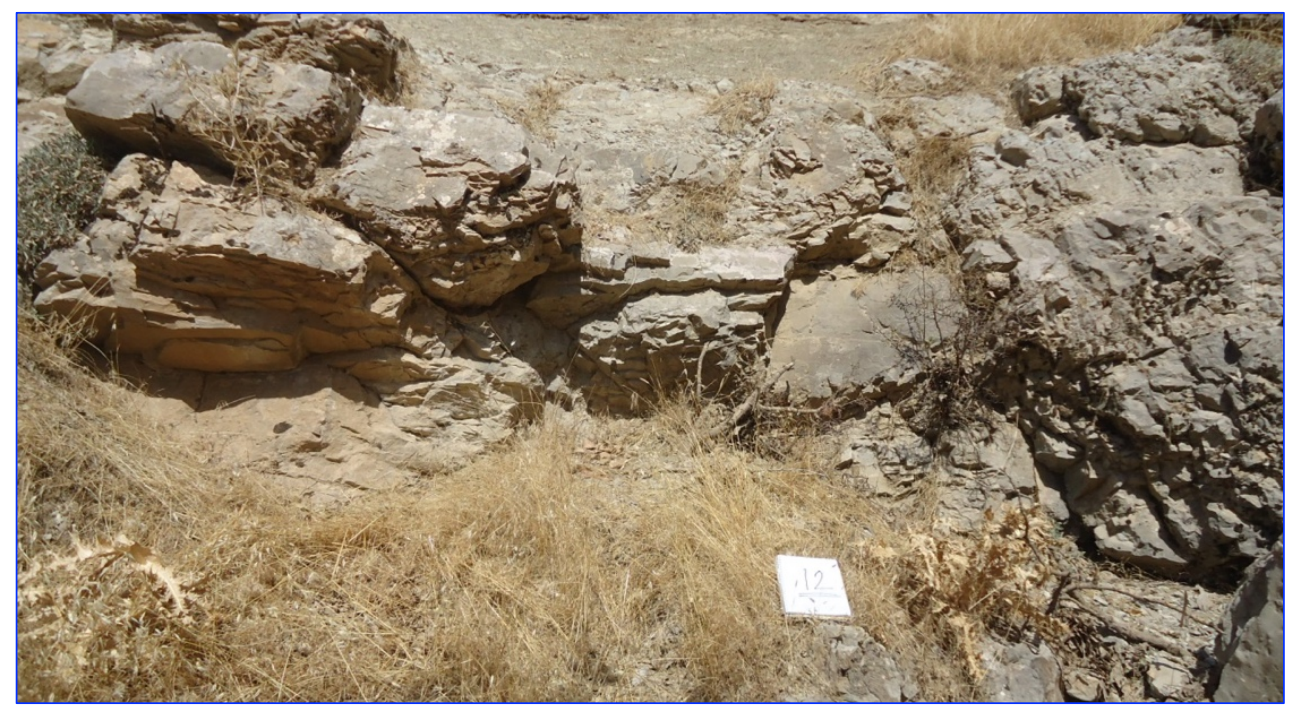

Fig. 3. Dolomite rocks of the Qamchuqa Formation in the slope station no. 12

\section{Shiranish Formation}

This Formation mainly contains thin bluish marly limestone of about $20 \mathrm{~m}$ thick at the lower part and the upper part consists of Marlstone (Fig. 4), also underlined Formation is the Behkme Formation (Jassim and Golff, 2006).

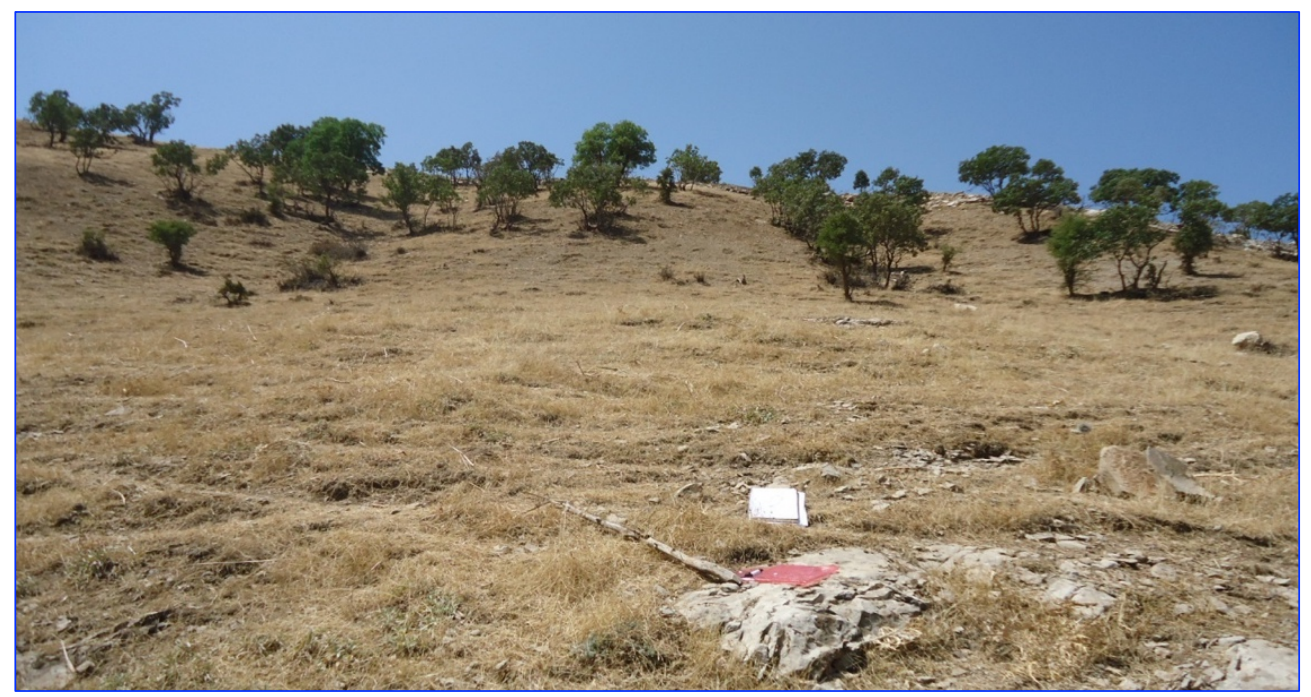

Fig. 4. The Shiranish Formation covered by recent deposit and vegetation in the slope station no. 2

\section{Bekhme Formation}

This Formation consists of basal conglomerate and foraminiferal marl at the base, reefal limestone with rudist debris in the middle and the upper part is composed of very hard dolomite containing rudist (Buday, 1980). Having bituminous materials in the lower and middle part (Omar, 2005) (Fig. 5). 


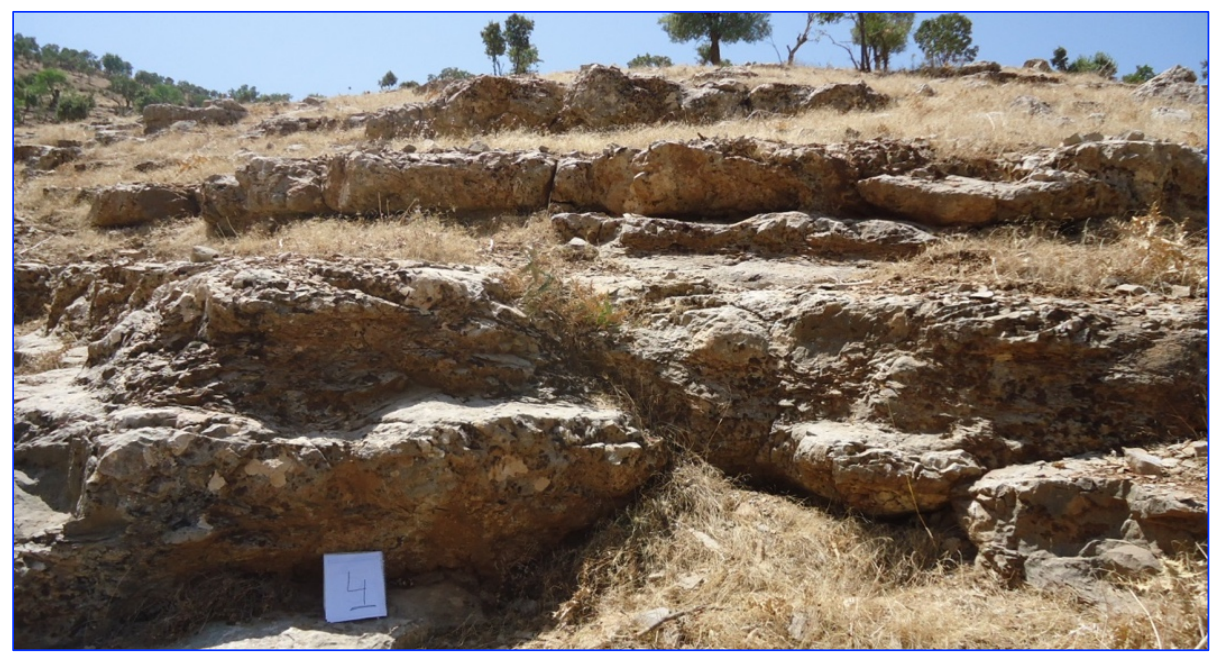

Fig. 5. Rocks of the Bekhme Formation in the slope station no. 4

\section{Sarmord Formation}

In the study, this formation is exposed in a different location at the Bradost anticline (Omer, 2005), in addition the thickness ranges from $80-130 \mathrm{~m}$. In the studied area mainly consists of weak, gray beds of shale which are rich in organic materials overlain by thick beds of limestone, moreover, well-bedded, dark gray-brown in color of marly limestone appear in the lower and middle part with 2-4 m thick, also the upper part contains limestone or dolomitic limestone, well bedded gray to brown in color with 1-3 m thick (Fig. 6) (Buday, 1980).

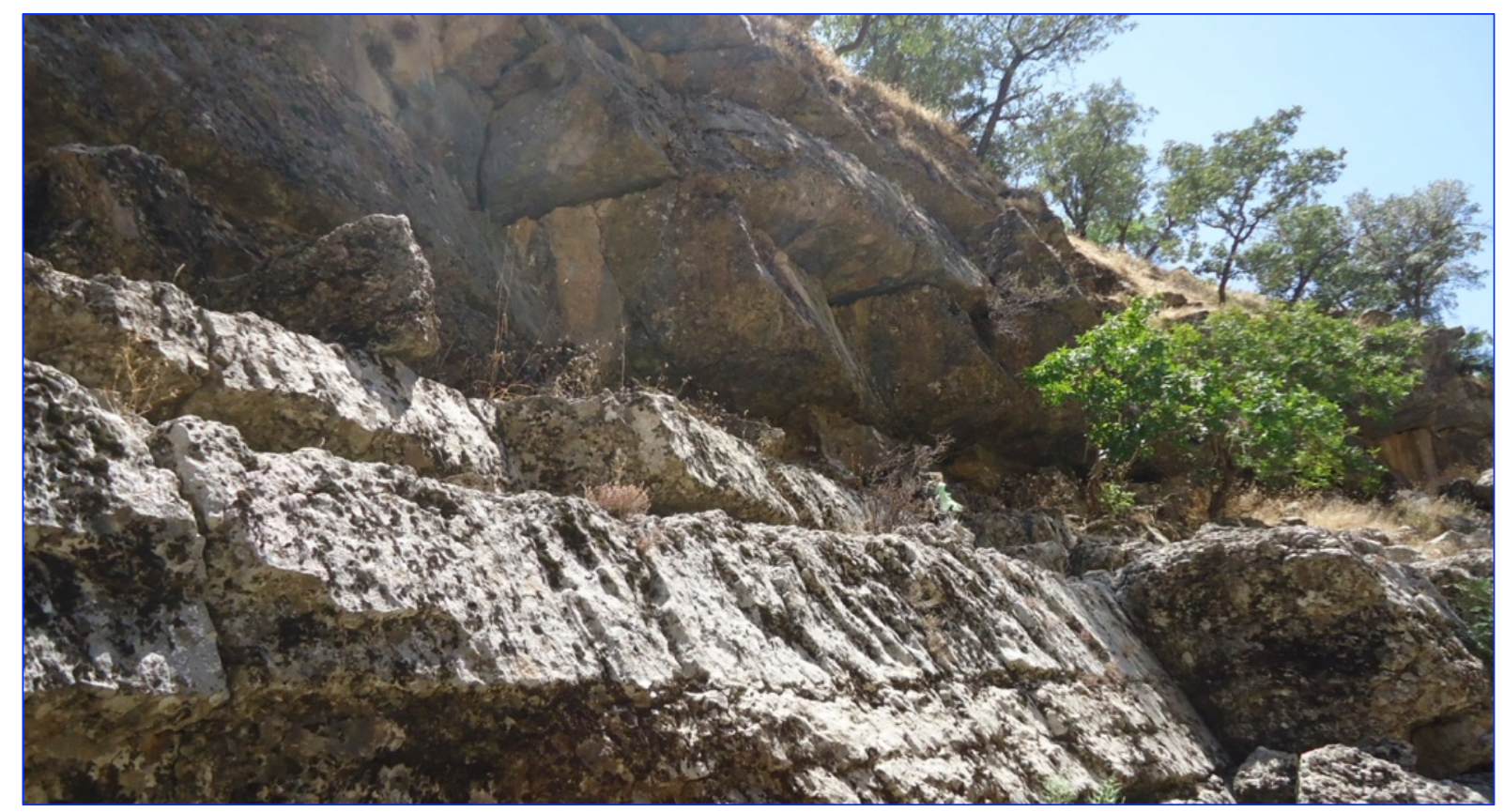

Fig. 6. Rocks of the Sarmord Formation in the slope station no. 20 


\section{Geomorphology}

Tectonic-erosional resulted in the anticlinal ridge of Bradost due to the differential erosion between the dolomite and limestone exposed in the core and the removed overlying rocks of the Bradost anticline. Moreover, the erosion of the NE limb produced parallel and sub-parallel drainage patterns and also effect of major fractures resulted in the production of deep valleys due to the widening of fractures by the solution and erosional actions as in Fig.7. Depositional origin of the features is represented by the landforms of slope processes origin, which includes delluvial, prolluvial and colluvial process. Delluvial process is washing loose material down the slope by waters resulting from rain and melting of snow and the transported materials are deposited in the base of the slope decreasing the slope angles (Fig. 7). Prolluvial process is restricted to the strong temporary waters running through gullies and channels and the removed materials includes both loose materials and blocks of various sizes due to the strong, short lasting kinetic energy of water (Stevanovic and Markovic, 2003). The colluvial process develops under direct influence of gravity force and the removal materials include slid and fallen blocks of various sizes.

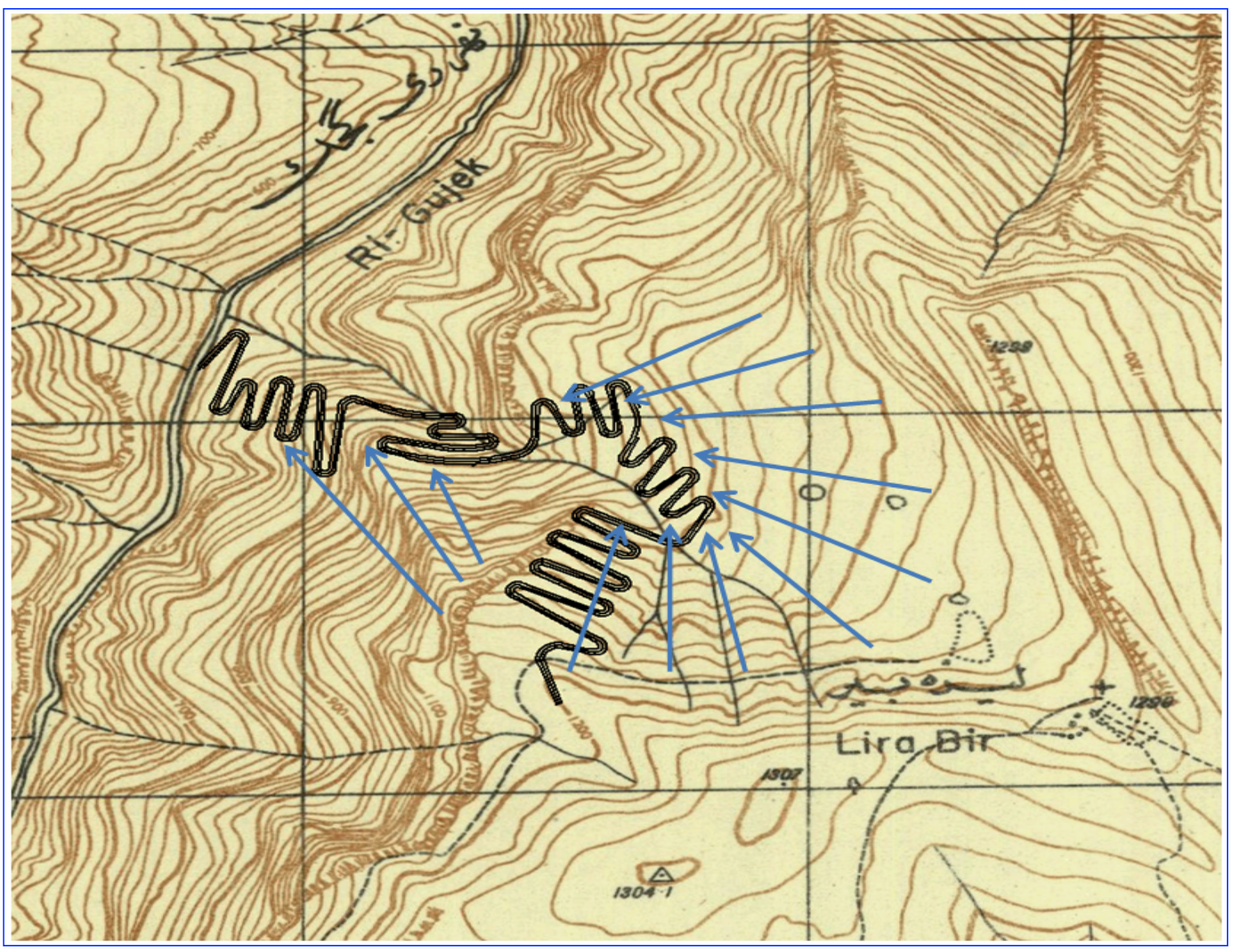

Fig. 7. Topographic map of the study area with proposed road and the direction of the water movement and snow melting 


\section{CLIMATE CONDITIONS}

The study area is located in the mountainous region of Iraqi Kurdistan that follows the Mediterranean climatic conditions which are characterized by wet cold winter and dry summer. Climatic factors play important role in the stability of slopes, especially, air temperature and rainfall that affect the weathering processes and ground water in the area which in turn influence the strength of the rock mass. At this study, for obtaining meteorological data it was referenced to the Climate Change Knowledge Portal (CCKP, 2018), because, the meteorological data is updated about the study area. The highest average monthly air temperature in the study area over the period 1991-2015 were at summer and during July and August reaches to $35^{\circ} \mathrm{C}$ and $36^{\circ} \mathrm{C}$ respectively, and the lowest air temperature was in winter and during January and December reaches to $10^{\circ} \mathrm{C}$. Moreover, there is big daily amplitude of air temperature at the area and based on the data from Mergasur city at some 14 $\mathrm{km}$ northeast of the study area (Fig. 8). The average annual rainfall in a Mergasur area over the period 1991-2015 was $44 \mathrm{~mm}$. the rain season starts from January to May and lasts of October and December months with the greatest amount of precipitation in the area are April, March, February, November and December. In the study area during rainy seasons, the excess water flows on the slope surface and bring rock fragments of various sizes down slopes. This is more dangerous for the proposed road and the bridge at the entrance of the valleys due to the high volume and energy of water which brings larger blocks, in addition to mud flow (as reported by residents and field observations) which is a predominant phenomenon at these parts during intense rainfall. This indicates the great role of water and its negative influence in the area (Fig. 9).

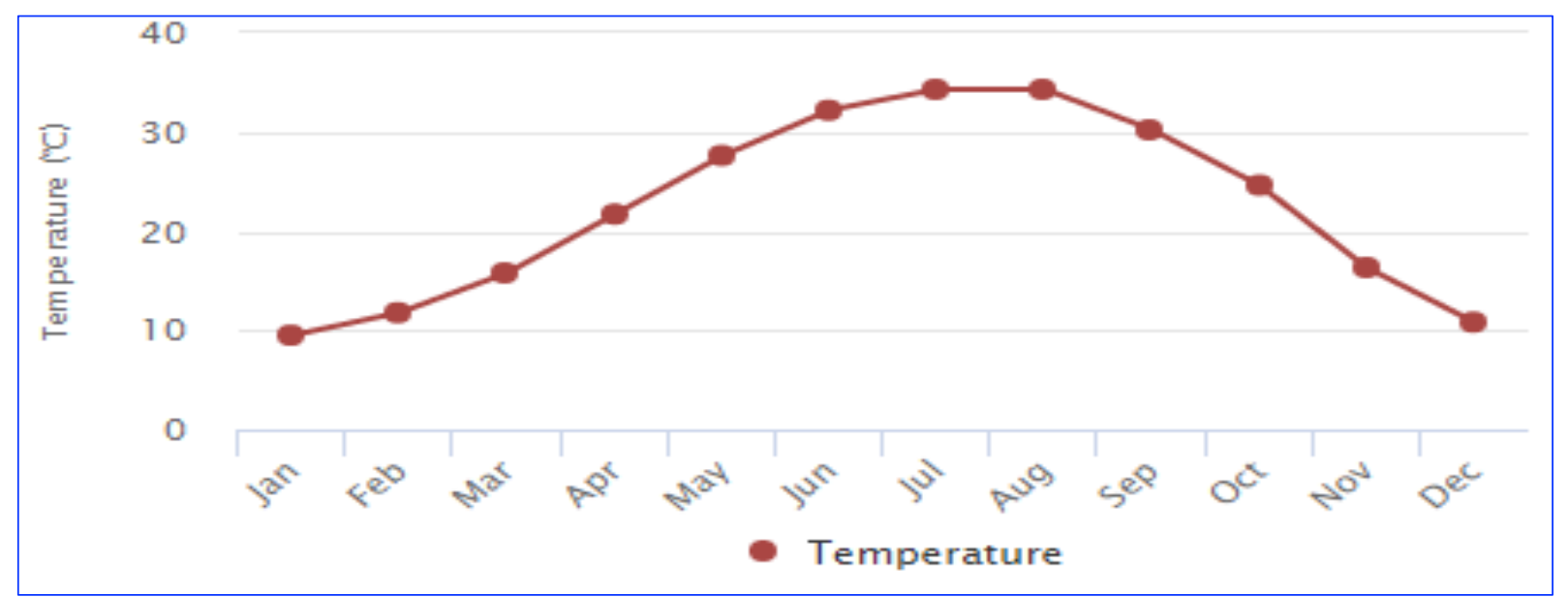

Fig. 8. Average monthly temperatures in Mergasur area for the period 1991-2015 (CCKP, 2018) 


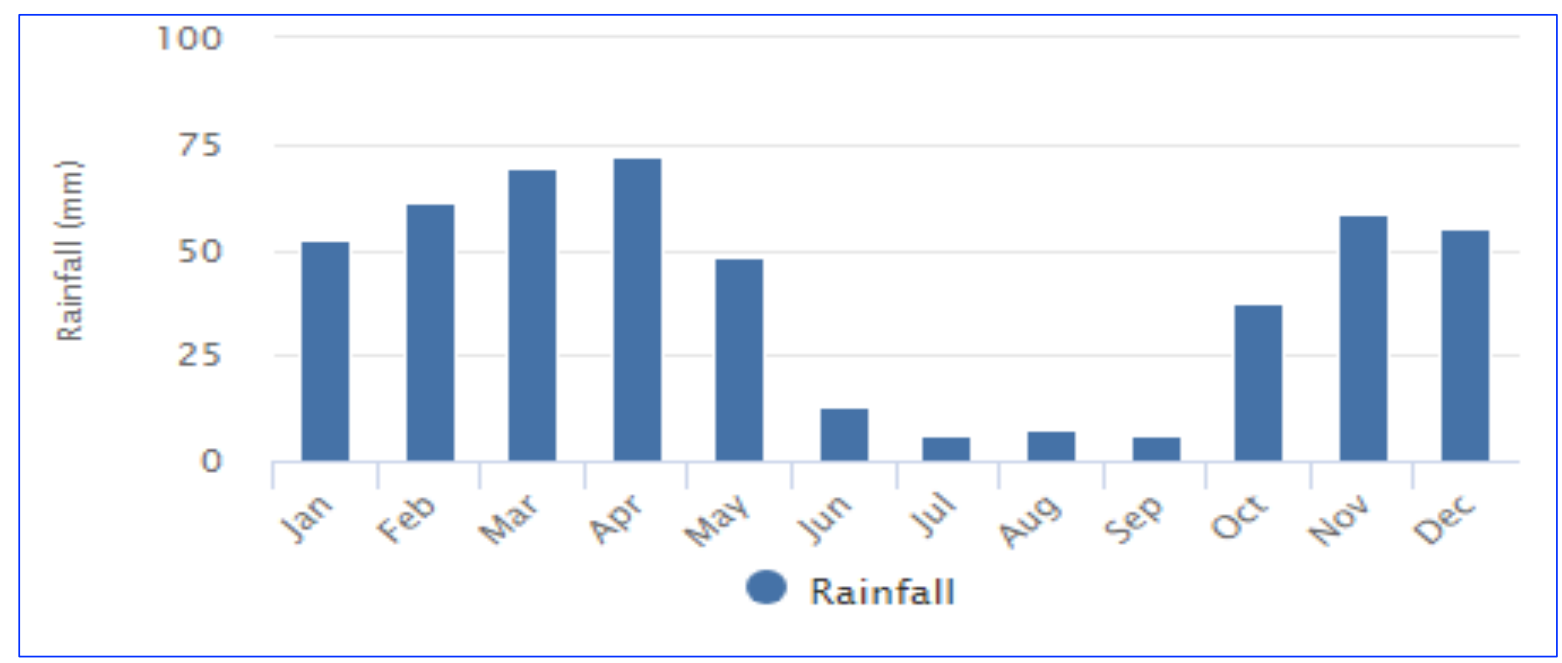

Fig. 9. Average monthly rainfall in Mergasur area for the period 1991-2015(CCKP, 2018)

\section{MATERIALS AND METHODS}

Slope stability analysis can be applied by using a series of classification systems, the Landslide Possibility Index system (LPI) (Bejerman, 1994) is one of those systems. This system is easy to use because basically depend on the field estimation and measurement only without referring to use laboratory tests. The main characteristic features of the rock slope calculated in many sites depending on Bejerman (1994) system by filling the sheet that considers (10) ten factors. The Landslide Possibility Index (LPI) and their parameters basically depending on slope circumstances, discontinuity properties and climate conditions in the rock slopes along the proposed road in the study area. The rock slope failure possibility in the study area was categorized based on LPI system values, furthermore, this value showing the landslide hazard category. In the study area the landslide hazard map has been drawn depending on hazard category values according to Bejerman (1994 and 1998).

\section{Rock Slope Stability Assessment According to the Landslide Possibility Index (LPI)}

The Landslide Possibility Index permits to assess the landslide possibility for rock slopes cut in mountainous roads (Bejerman, 1994). This estimation system takes into consideration ten characteristic features of the slope estimated in the field and later integrated in the LPI-chart such as that in Table 1. Moreover, the geological, structural, hydrological and geomorphological conditions in the study area are the main evaluation for each feature in the LPI-chart. Base in determining the hazard category and according to TRB (1996) and Ritchie (1963) suggested some remediation techniques to the rock slopes in the proposed road in the study area. The remediation techniques selected based on the applicability on the slope. 


\section{Failure Hazard Zonation According to LPI Values}

When the parameters are estimated in Table 1, the values for each factor is calculated then the obtained values are added up in order to determine the LPI for the slope. Table 2 shows the degree of hazard that classified to three categories base on the LPI value (Bejerman, 1994), also hazard map has been drawn depending on LPI values according to Bejerman (1994 and 1998).

Table 1. Chart of Landslide Possibility Index (LPI) features (After Bejerman, 1994)

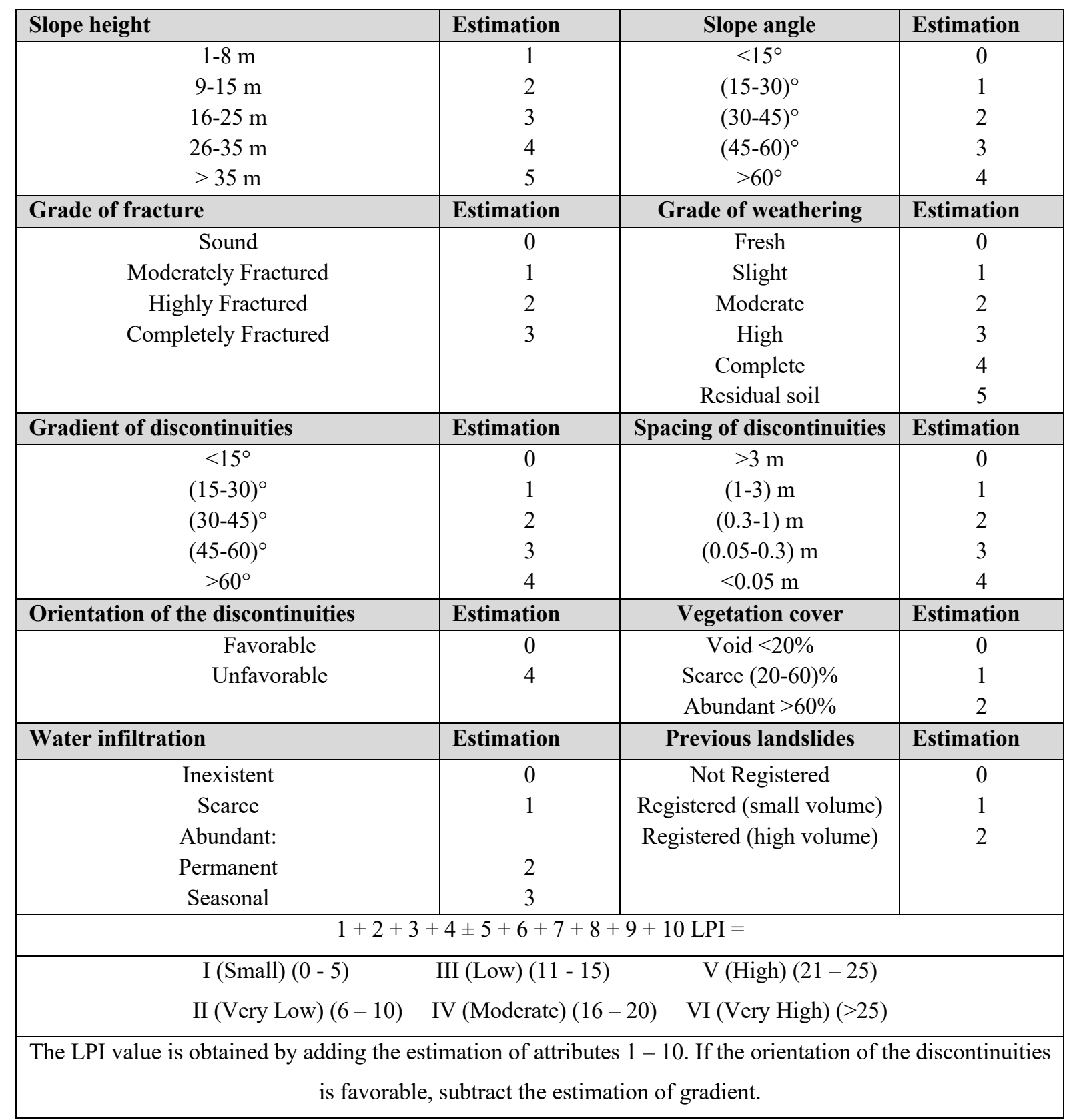


Table 2. Landslide Possibility Index and hazard categories (Bejerman, 1994 and 1998)

\begin{tabular}{|c|c|c|c|c|}
\hline \multicolumn{3}{|c|}{ Landslide Possibility Index } & \multirow{2}{*}{\multicolumn{2}{|c|}{ Hazard category }} \\
\hline Grade & Category & Estimation & & \\
\hline VI & Very High & $>25$ & \multirow{2}{*}{$>21$} & \multirow{2}{*}{ High Hazard } \\
\hline $\mathrm{V}$ & High & $21-25$ & & \\
\hline IV & Moderate & $16-20$ & \multirow{2}{*}{$11-20$} & \multirow{2}{*}{ Moderate Hazard } \\
\hline III & Low & $11-15$ & & \\
\hline II & Very low & $6-10$ & \multirow{2}{*}{$<10$} & \multirow{2}{*}{ Low hazard } \\
\hline I & Small & $0-5$ & & \\
\hline
\end{tabular}

\section{RESULTS AND DISCUSSIONS}

Twenty stations of rock slopes were studied in details in the study area, in the Qamchuqa, Shiranish, Bekhme and Sarmord formations rock slopes. The main focus of this paper is the assessment of the possibility of landslides and degree of hazards on the rock slopes in the proposed road according to Bejerman (1994).

\section{Landslide Possibility Index (LPI) in the Study Area}

The LPI classification according to Bejerman (1994) is applied in all the stations along the proposed road. The landslide possibility is categorized in Table 1 to six groups: (I) Small (LPI=0-5), (II) Very Low (LPI=6-10), (III) Low (LPI= 11-15), (IV) Moderate (LPI= 16-20), (V) High (LPI= 21-25) and (VI) Very High (LPI > 25). Table 3 illustrates the summary of the Landslide possibility Index (LPI) system of the rock slope stations in the study area and 10 characteristic features was measured in the field are demonstrated in the Table 3. In addition, the rock slopes in the study area are described as follows;

The stations 1 and 2 in the Shiranish Formation rock slopes have very low to low LPI values (Table 3) because it is mostly covered by recent sediment and no previous landslides were observed in those stations, also the slopes remain in stable situation due to absence of unfavourable discontinuities, the rocks have sound fracture and this make the rock blocks become stable in the slope. The stations 3,4 and 19 in the Behkme Formation rock slopes, have moderate LPI values (Table 3) because they are the high slope face and unfavourable discontinuities with high slope angles in the limestone bed slopes, but station 19 is favourable discontinuities in the limestone rock slope. The rock slopes at the station 5 to 11 in the Behkme Formation, station 12 and 17 in the Qamchuqa Formation and station 20 in the Sarmord Formation have a high value of LPI (Table 3) because of the steepness, high rock slope and unfavourable discontinuities. The other stations 13,14,14a,15 and 16 in the Qamchuqa Formation and station 18 in the Behkme Formation have very high values of LPI 
because of the steep slope, high slope angle, highly to complete fractured rocks especially in the limestone rock bed with highly weathered ratings and unfavourable discontinuities. In Table 3 the values of LPI are calculated for all stations along the proposed road.

Table 3. Summary of Landslide possibility Index (LPI) system of the rock slope stations in the study area

\begin{tabular}{|c|c|c|c|c|c|c|c|c|c|c|c|c|c|}
\hline \multirow{2}{*}{$\begin{array}{l}\text { Rock slope station no. and formation } \\
\text { (Fn.) }\end{array}$} & \multicolumn{10}{|c|}{ Characteristic features of the slope } & \multirow{2}{*}{$\frac{0}{\frac{0}{\pi}}$} & \multirow{2}{*}{$\vec{G}$} & \multirow{2}{*}{ 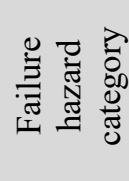 } \\
\hline & 1 & 2 & 3 & 4 & 5 & 6 & 7 & 8 & 9 & 10 & & & \\
\hline Shiranish Fn. & 1 & 0 & 0 & 5 & 0 & 0 & 0 & 1 & 3 & 0 & 10 & V.L. & L. \\
\hline Shiranish Fn. & 3 & 2 & 2 & 3 & -1 & 1 & 0 & 1 & 1 & 0 & 12 & $\mathrm{~L}$. & M. \\
\hline Bekhme Fn. & 2 & 1 & 2 & 3 & 4 & 0 & 4 & 0 & 1 & 0 & 17 & M. & M. \\
\hline Bekhme Fn. & 1 & 1 & 1 & 2 & 4 & 2 & 4 & 1 & 1 & 0 & 17 & M. & M. \\
\hline Bekhme Fn. & 3 & 2 & 1 & 2 & 2 & 3 & 4 & 1 & 3 & 0 & 21 & H. & H. \\
\hline Bekhme Fn. & 3 & 2 & 1 & 2 & 2 & 3 & 4 & 1 & 3 & 0 & 21 & H. & $\mathrm{H}$. \\
\hline Bekhme Fn. & 3 & 2 & 1 & 2 & 2 & 3 & 4 & 1 & 3 & 0 & 21 & H. & $\mathrm{H}$. \\
\hline Bekhme Fn. & 3 & 2 & 2 & 2 & 4 & 2 & 4 & 1 & 1 & 0 & 21 & H. & H. \\
\hline Bekhme Fn. & 3 & 2 & 2 & 2 & 4 & 2 & 4 & 1 & 1 & 0 & 21 & $\mathrm{H}$. & H. \\
\hline Bekhme Fn. & 4 & 2 & 2 & 3 & 0 & 2 & 4 & 2 & 3 & 0 & 22 & $\mathrm{H}$. & $\mathrm{H}$. \\
\hline Bekhme Fn. & 1 & 1 & 1 & 5 & 2 & 2 & 4 & 2 & 3 & 0 & 21 & H. & H. \\
\hline Qamchuqa Fn. & 3 & 2 & 2 & 4 & 3 & 2 & 4 & 1 & 3 & 0 & 24 & $\mathrm{H}$. & $\mathrm{H}$. \\
\hline Qamchuqa Fn. & 4 & 2 & 3 & 4 & 3 & 2 & 4 & 1 & 3 & 0 & 26 & V.H. & H. \\
\hline Left abutment bridge Qamchuqa Fn. & 4 & 4 & 3 & 4 & 4 & 2 & 4 & 0 & 3 & 0 & 28 & V.H. & H. \\
\hline Middle bridge Qamchuqa Fn. & 4 & 4 & 3 & 4 & 4 & 2 & 4 & 0 & 3 & 0 & 28 & V.H. & H. \\
\hline Right abutment bridge Qamchuqa Fn. & 5 & 4 & 3 & 3 & 4 & 2 & 4 & 0 & 3 & 0 & 28 & V.H. & H. \\
\hline Qamchuqa Fn. & 4 & 4 & 3 & 3 & 4 & 2 & 4 & 0 & 3 & 0 & 27 & V.H. & H. \\
\hline Qamchuqa Fn. & 4 & 4 & 2 & 3 & 4 & 1 & 4 & 0 & 3 & 0 & 25 & $\mathrm{H}$. & H. \\
\hline Bekhme Fn. & 5 & 4 & 2 & 3 & 4 & 2 & 4 & 1 & 3 & 0 & 28 & V.H. & H. \\
\hline Bekhme Fn. & 5 & 4 & 3 & 4 & -4 & 3 & 0 & 2 & 3 & 0 & 20 & M. & M. \\
\hline Sarmord Fn. & 3 & 3 & 2 & 3 & 3 & 2 & 4 & 1 & 3 & 0 & 24 & $\mathrm{H}$. & H. \\
\hline
\end{tabular}

Where; V.L.; Very low, L.; Low, M.; Moderate, H.; High and V.H.; Very high

\section{Failure Hazard Categories According to (LPI) Values}

Failure hazard categories illustrated in the Table 2, the rating depends on the LPI values (Bejerman, 1994 and 1998). Hazard categories are classified into three categories as follow:

a) Low hazard category: contain two LPI categories: (I) Small (LPI= 1-5) and (II) Very Low $(\mathrm{LPI}=6-10)$.

b) Moderate hazard category: contain two LPI categories: (III) Low (LPI= 11-15) and (IV) Moderate (LPI= 16-20).

c) High hazard category: contain two LPI categories: (V) High (LPI= 21-25) and (VI) Very High (LPI > 25).

\section{Failure Hazard Assessment in the Study Area, According to (LPI) Values}

The LPI field assessment for the rock slopes in all stations along the proposed road is described as follows; Only station 1 in the Shiranish Formation of marl and limestone rock slopes has a low hazard slope (Tables 2, 3 and 4) due to small to very low LPI values. Station 
2 in the Shiranish Formation of marl rock slopes and stations 3, 4, and 19 in the Behkme Formation of limestone rock slopes, they have moderate hazard slopes due to low to moderate LPI values (Tables 2, 3 and 4). Also, stations 5 to 11 and 18 in the Behkme Formation of limestone rock slopes, stations 12 to 17 in the Qamchuqa Formation of limestone and marly limestone rock slopes and station 20 in the Sarmord Formation of limestone rock slopes, they have high hazard slope due to high to very high LPI values (Tables 2, 3 and 4). Moreover, the data in Tables 3 and 4 are used for drawing the landslide hazard map for the study area along the proposed road (Fig. 10).

Table 4. Landslide hazard category in the rock slopes according to LPI values

\begin{tabular}{|c|c|c|}
\hline Number of stations & $\begin{array}{c}\text { LPI } \\
\text { Category }\end{array}$ & $\begin{array}{l}\text { Hazard } \\
\text { category }\end{array}$ \\
\hline Station 1 in Shiranish Formation (marly and limestone rock slope) & $0-10$ & Low \\
\hline $\begin{array}{l}\text { Station } 2 \text { in Shiranish Formation (marl rock slope) } \\
\text { Station 3, } 4 \text { and } 19 \text { in Behkme Formation (limestone rock slopes) }\end{array}$ & $11-20$ & Moderate \\
\hline $\begin{array}{l}\text { Station } 5 \text { to } 11 \text { and } 18 \text { in Behkme Formation (limestone rock slopes) } \\
\text { Station } 12 \text { to } 17 \text { in Qamchuqa Formation (limestone and marly limestone rock slopes) } \\
\text { Station } 20 \text { in Sarmord Formation (limestone rock slopes) }\end{array}$ & $>21$ & High \\
\hline
\end{tabular}

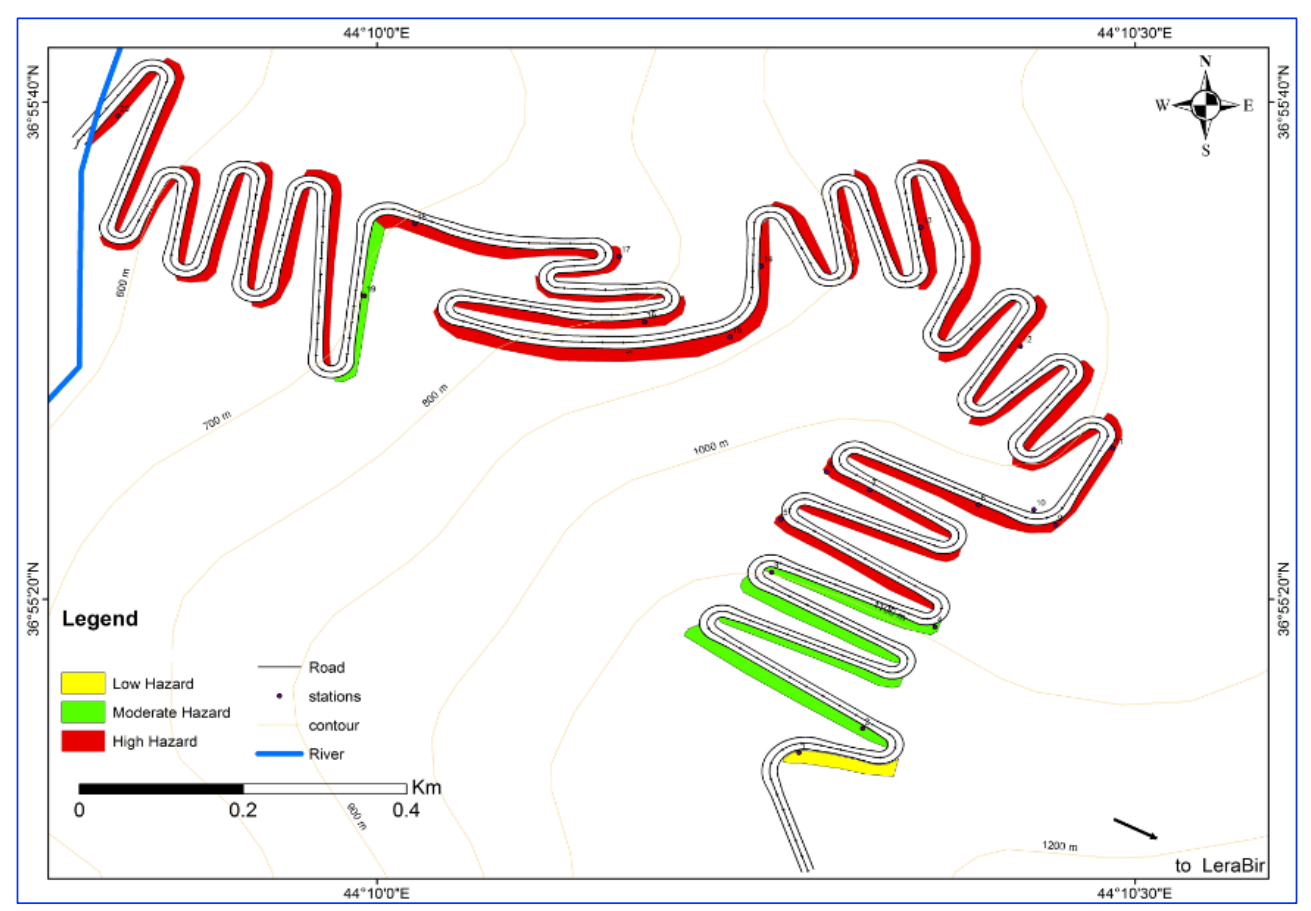

Fig. 10. Longitudinal failure hazard map for the proposed road, according to LPI value

\section{Prevention Landslide Hazard of Rock Slope in Study Area}

Constructing the road in the mountainous terrain is a complex civil work that includes cut and fill process in the rock slopes, in addition the rock slopes should be in a stable condition in a point view of geology, structure and environment, otherwise the slopes required the 
treatment after cutting, the following are the formations that appear in the study area during the road construction.

\section{Prevention Landslide of the Shiranish Formation Rock Slopes}

The rock slope in the Shiranish Formation is characterized by sound fractured, completely weathered, thick bed and low joint space, moreover, during the cutting slope face the bedding plane are dipping in a direction of slope face and the possible failure occur in stations 1 and 2. Also unstable rock blocks are another possibility failure to occur. The slope faces protection is required, needs the ditches to catch the unstable rock fragments about 3-3.5 m width to contain fallen rock, in addition (Ritchie, 1963) (Fig. 11) illustrated that the ditch $4.75 \mathrm{~m}$ width and $1.8 \mathrm{~m}$ depth will be practical for the slope with slope height $30 \mathrm{~m}$. The rock removal is required for unstable rock blocks after cutting rock slopes (Fig. 13).

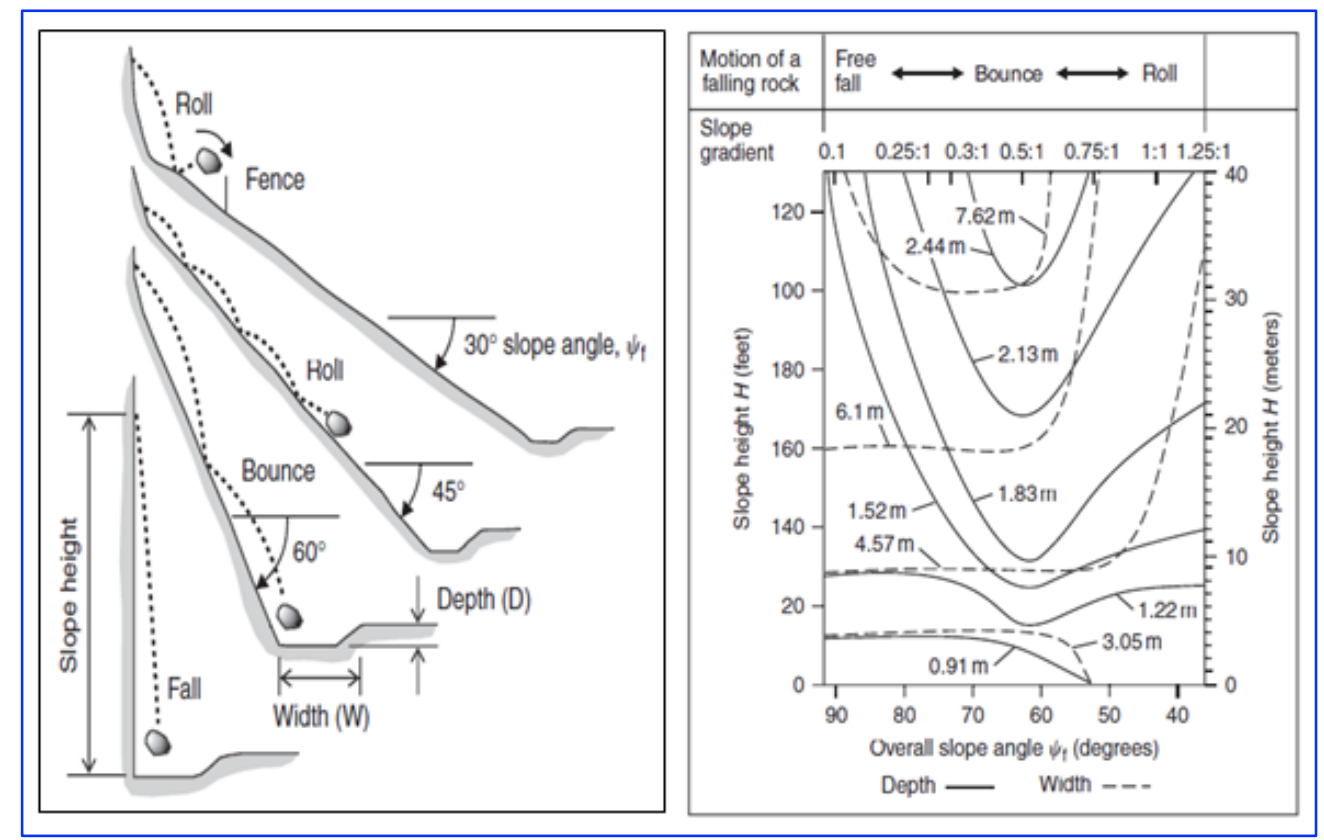

Fig. 11. Ditch design chart for rock fall catchment (Ritchie, 1963)

\section{Prevention Landslide of the Bekhme Formation Rock Slopes}

The rock slopes in the Behkme Formation are characterized by highly fractured, highly weathered, compressive strength, thick bed and highly joint space. According to this physical properties the possible failure in the station 3 to 11,18 and 19 in addition the bedding planes dipping less than the slope angle that is makes the daylight bedding planes in slope face, also the slope angle in stations 18 and 19 almost vertical after cutting the slope, the remediation is require to stabilize the rock slope using the rock slope reinforcement such as tensioned rock bolts in a displaced rock blocks (Fig. 12a) and untensioned dowels with fully grouted before starting the excavation process (Fig. 12b) (TRB, 1996). 


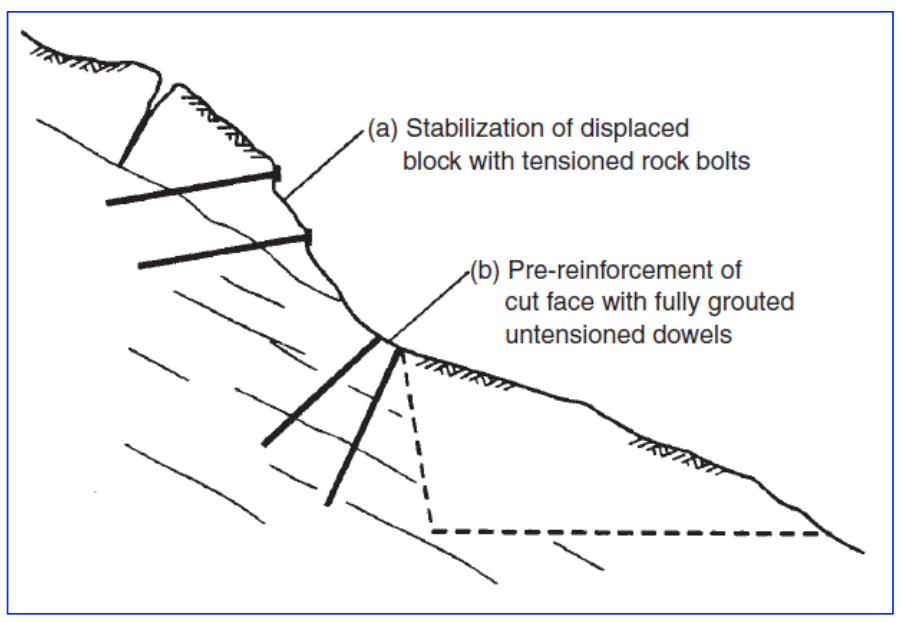

Fig. 12. Reinforcement of a rock slope (TRB, 1996)

\section{Prevention Landslide of the Qamchuqa Formation Rock Slopes}

The Qamchuqa Formation rock slopes are characterized by highly to completely fractured, highly weathered, thick bed, very steep slope, different type of fault and highly joint space. In stations 12 to 17 , the bedding planes dipping opposite to the slope angle and that is indicate the favourable for stability. Stations 12 to 17 lithologically consists of limestone and marly limestone moreover, the weathering has the significant impact on the stability of the rock slopes in those stations because the marl is easily affected by erosion process. Base on that the slope faces protection is required, it needs the ditches to catch the unstable rock fragments about 4-4.5 m width to contain fallen rock and fragments, Ritchie (1963) illustrated that the ditch $7.5 \mathrm{~m}$ width and $1.8 \mathrm{~m}$ depth will be more useful for the slope with a slope height more than $30 \mathrm{~m}$ (Fig. 11). Stations 14 and 15 (Fig. 14 and 15) when the bridge abutment is applied in the proposed road, the main stabilization measures required for slope face is a rock removal by removing the unstable blocks, reslopping and removing trees on the slope in the surrounding area (TRB, 1996) (Fig. 13), the location of the bridge is on the changing slope of the valley that start from the top of the mountain to the base, changing the slope at this location will increase the speed of the water or snow movement during the winter seasonal. The middle pile of the bridge is located on the center of the valley that sloping is changing also station $14 \mathrm{a}$, the slope protection at this point is drainage to change the direction of water movement to the both sides of the pile because the foundation of this pile is on the rock fall that collapsed from the surrounding slopes.

\section{Prevention Landslide of the Sarmord Formation Rock Slopes}

The station 20 rock slope lithologically consists of limestone with highly fractured, widely joint spaces and highly weathered (Fig. 6). During cutting the rock slopes, the slope support is removed, but the bedding planes dipping opposite to the slope angle and that is indicated the 
favourable for stability. For prevention the landslide, the rock removal is required by removing the unstable blocks, resloping and removing trees on the slope in the surrounding area (TRB, 1996) (Fig. 13).

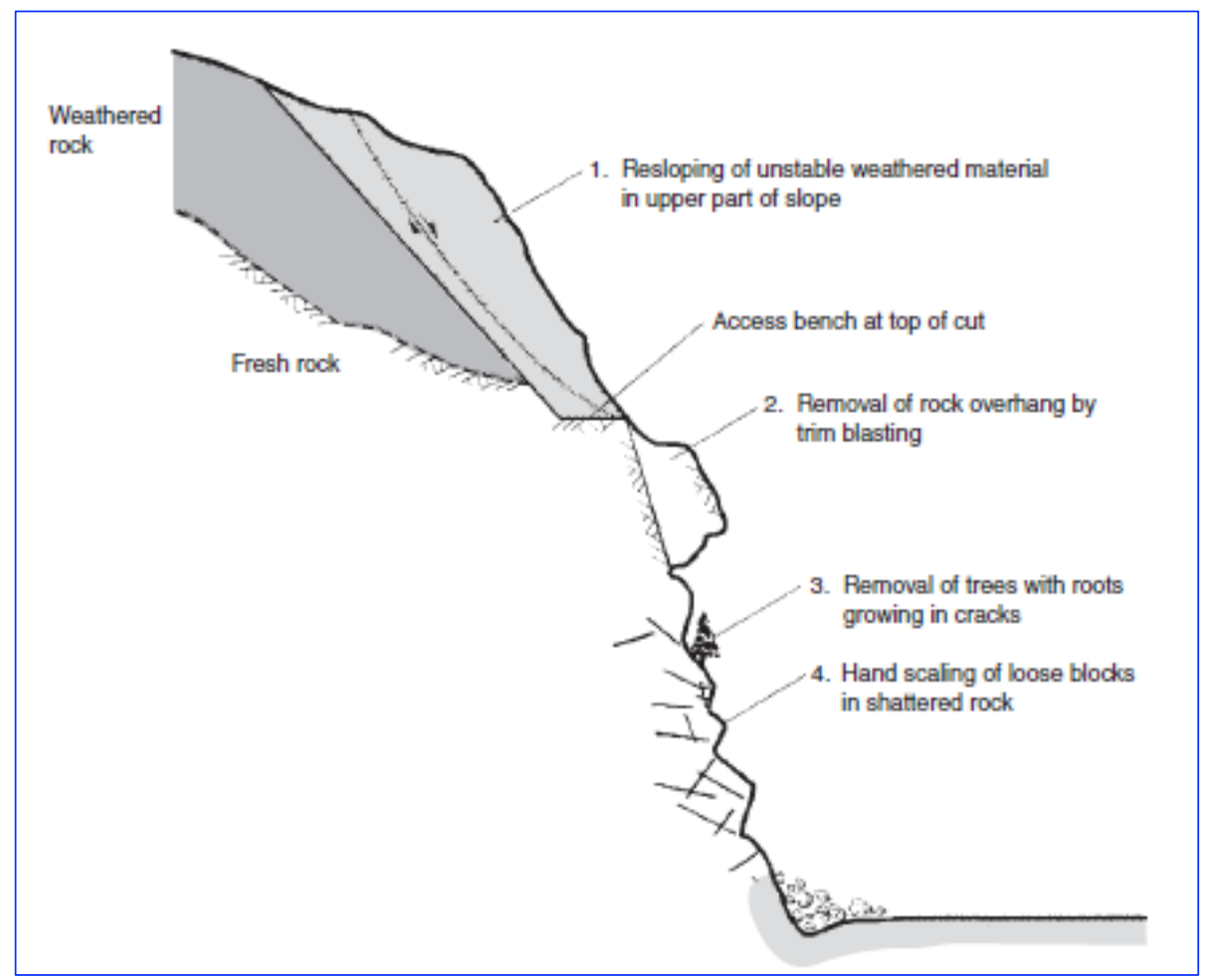

Fig. 13. Rock removal methods for slope stabilization (TRB, 1996)

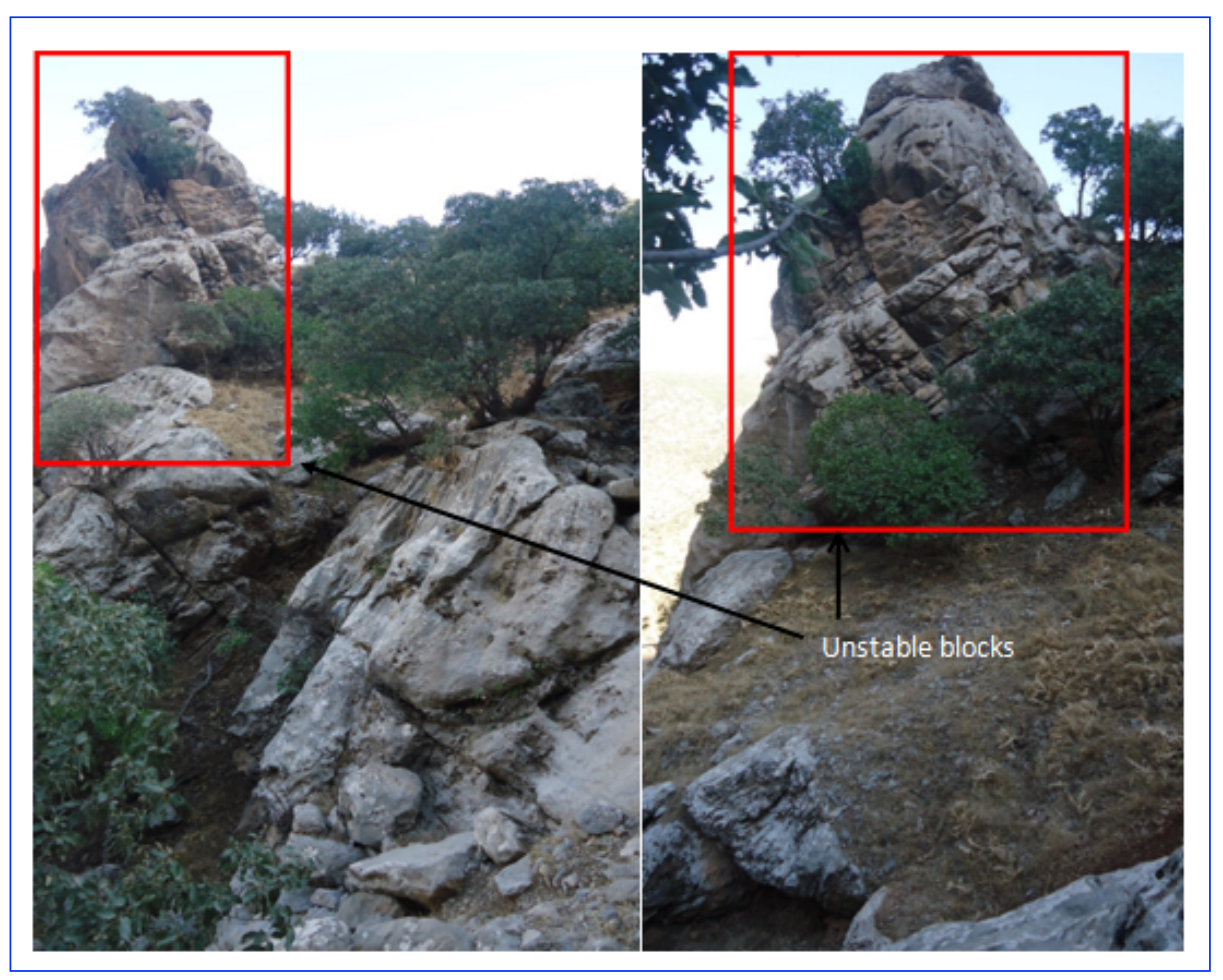

Fig. 14. Unstable blocks in the rock slope - station 14 in the proposed road 


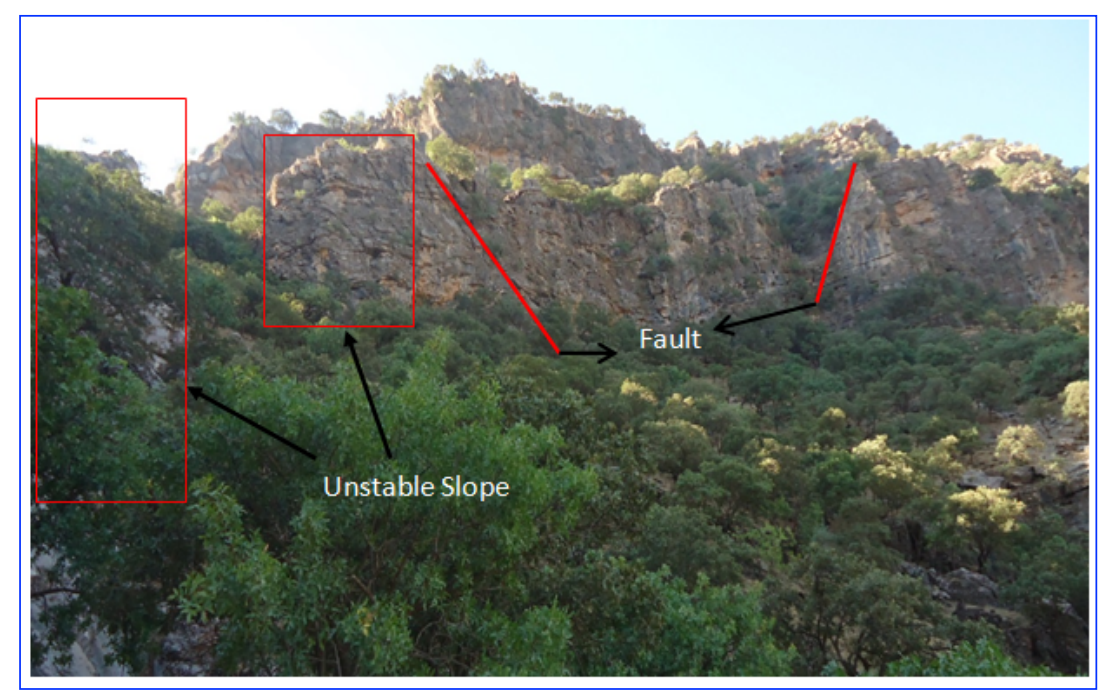

Fig. 15. Unstable slope face in station 15 rock slopes

CONCLUSIONS

The followings are concluded in the study area along the proposed road:

- The Landslide possibility index (LPI) system is considered as a method for determining the degree of the failure possibility in the rock slopes. In addition, this system used and point out very low to a very high degree of failure possibility in the rock slopes depending on LPI value.

- In this study the LPI category is calculated from 20 stations in the rock slopes based on LPI values (Stations 1 and 2) very low to low, (Stations 3, 4 and 19) is moderate, (Stations 5 to 11,12 to 17 and 20) is high and (Stations 13, 14, 14a, 15, 16 and 18) is a very high LPI category.

- The Hazard category is calculated from 20 stations in the study area based on LPI category; (Station 1) is low hazard, (Stations 2, 3, 4, and 19) is moderate hazard and (Station 5 to $11,18,12$ to 17 and 20) is high hazard, base on that the hazard map prepared.

- The rock slope analysis illustrated that the height of slope face, slope angle, high degree of weathering and discontinuities spacing are the factors that increase the failure possibility in the rock slopes.

- To prevent landslide of the rock slopes in the study area, the ditch method is used in the Shiranish Formation rock slopes, the reinforcement techniques are used in the Behkme Formation rock slopes and rock removal method are used in Qamchuqa and Sarmord formations rock slopes. 


\section{ACKNOWLEDGMENTS}

The authors need to express gratitude to the HMH Group Company and Survey Engineer Amin Rahman for their support and guiding during the field measurement. The authors are very grateful to the Editor in Chief Prof. Dr. Salih M. Awadh, the Secretary of Journal Mr. Samir R. Hijab and the Technical Editor Dr. Heba S. Al-Mimar for their great efforts and valuable comments.

\section{REFERENCES}

Alhadad, K. A., 2020. Hazard assessment of slope failures in conglomeret at Tikrit, Northern Iraq. Iraqi Geological Journal, 53 (1C): 121-135.

Al-Sinawi, S. A. and Al Qasrani, Z., 2003. Earthquake hazards considerations for Iraq. 4th International Conference of Earthquake Engineering and Seismology, May 2003 Tehran, Islamic Republic of Iran.

Balaki, H. G. K., and Omar, A. A., 2019. Structural assessment of the Bradost and Berat structures in Imbricate and High Folded zones-Iraqi Kurdistan Zagros belt. Arabian Journal of Geosciences, 12:106.

Bejerman, N. J., 1994. Landslide possibility index system. Proceedings 7th Int. IAEG congress, Balkema, Rotterdam, 3:1303-1306.

Bejerman, N. J., 1998. Evaluation of Landslide susceptibility along state road 5 Cordoba, Argentina. Proceedings 8th International. congress of IAEG, Balkema, Rotterdam, 2:1175-1178 .

Buday, T. and Jassim, S. Z., 1987. The Regional Geology of Iraq,.Baghdad, Iraq, 2: 352 .

Buday, T., 1980. The Regional Geology of Iraq, Stratigraphy and Paleogeography, 445p.

Climate Change knowledge Portal, 2018.

Fouad, S. F., 2010. Tectonic and structural evolution of the Mesopotamia Foredeep, Iraq. Iraqi Bulletin of Geology and Mining, 6(2): 41-53.

Ibrahim, S. B., Ahmed, F. T., Jawad, S. A., Kocho, K. I., and Al-Azzawi, A. R., 1984. Report on the photogeology of a part of the Folded Zone-Northern Iraq. GEOSURV, 1376, Baghdad, Iraq.

Jassim. S. Z. and Goff, J. C., 2006. Geology of Iraq. Published by Dolin, Praght and Moravian Museum, 150 p.

Omar, A. A., 2005. An Integrated Structural and Tectonic Study of the BinaBawi-Safin-Bradost Region in Iraqi Kurdistan. Ph.D. thesis, University of Salahaddin, 314 p.

Ritchie, A. M., 1963. The evaluation of rock fall and its control. highway record, 17: 13- 28 .

Sissakian, V. K., 1998. The geology of Erbile and Mahabad quadrangle sheet NJ-38- 15, Scale 1:250000. GEOSURV, 2462, Baghdad, Iraq.

Sissakian, V. K. and Al-Jiburi, B. S., 2014. Stratigraphy of the high folded zone. Iraqi Bulletin of Geology and Mining, (6): 73-161.

Son, B. T., Nu, N. T., Duong, N. T. and Ngoc, N. A., 2020. Application the point foundation (pf) method for soft soil improvement: a case study from Vetnam. Iraqi Geological Journal, 53 (2D):1-18.

Stevanovic, Z. and Markovic, M., 2003. Hydrogeology of northern Iraq field documents, climate, hydrology, geomorphology, geology, FAO coordination office for Northern Iraq, GWU, OSRO1 Iraq, 1: 129 .

Transportation Research Board (TRB) 1996. Landslides, investigation and mitigation. National Research Council, Special Report 247, Ch. 1, Washington DC, 673 p. 